\title{
Comparison of serum androgens and endometrial thickness in obese and non-obese postmenopausal women
}

\section{Obez ve obez olmayan postmenopozal hastalarda serum androjen seviyeleri ve endometrial kalınlığın karşılaştırıması}

\author{
İlker İnan Ankan'1, Aykut Barut ${ }^{1}$, Deniz Ankan², Müge Harma, Mehmet İbrahim Harma', Serpil Bozkurt ${ }^{3}$ \\ IDepartmentof Obstetrics and Gynecology, Faculty of Medicine, Zonguldak Karaelmas University, Zonguldak, Turkey \\ 2Department of Gynecology and Obstetrics, Faculty of Medicine, Kahramanmaraş Sütcü Imam University, Kahramanmaraş, Turkey \\ 3Department of Gynecology and Obstetrics, Faculty of Mediane, Maltepe University, İstanbul, Turkey
}

\section{Abstract}

0 bjective: In this study, we investigated whether serum androgen levels and endometrial thickness differed in obese and non-obese women. Material and Methods: Thirtytwo non-obese (BMI <30) and 48 obese $(\mathrm{BMI} \geq 30$ ) women were enrolled. Blood samples were analyzed for testosterone, free testosterone, androstenedione, DHEAS, and SHBG, and transvaginal ultrasonography was performed.

Results: Obese women had significantly higher free testosterone and endometrial thickness and significantly lower SHBG. Eight of 17 women with endometrial thickness $>5 \mathrm{~mm}$ had significant pathology. Conclusion: These results suggest that obesity may be a risk factor for endometrial carcinoma and other pathologies in post-menopausal women through an action on androgen concentrations.

(J Turkish-German Gynecol Assoc 2010; 11: 149-51)

Key words: Serum androgene, endometrial thickness, obesity, postmenopause

Received: 13 November, 2010

Accepted: 3 August, 2010

\section{Introduction}

The major hormonal changes associated with the occurrence of the final menstrual period (FMP) in normal subjects include a profound fall in circulating estradiol $\left(E_{2}\right)$, primarily of ovarian origin, beginning up to about one year earlier, and an accompanying large increase in the circulating gonadotropins, FSH and LH (1, 2). Changes in circulating androgens are more complex. In cross-sectional studies, levels of testosterone [T] have been reported to be lower in postmenopausal than premenopausal women $(3,4)$, whereas in the few longitudinal studies, either no change (5) or a small fall, of the order of $15 \%$ (2), in total T has been reported. The major adrenal androgen, dehydroepiandrosterone sulfate (DHEAS), reaches its peak levels in young women in their twenties and declines progressively thereafter, with no obvious relationship to the menopause (6). Serum sex hormone binding globulin (SHBG) levels fall to a small degree postmenopausally (1).

\section{Özet}

A maç: Bu çalışmamızda, endometrial kalınlık ve serum androjen seviyelerinin obez ve obez olmayan hastalardaki farklılı̆ı araştunlmıştr.

Gereç ve Yöntemler: 32 obez olmayan $(B M I<30)$ ve 48 obez ( $\mathrm{BMI} \geq 30$ ) hasta çalıșmaya dahil edildi. Hastalann serum testosteron, serbest testosteron, androstenedion, DHEAS, SHBG seviyeleri ölçüldü ve transvajinal ultrasonoğrafi yapıldı.

B ulgular: Obez hastalann serbest testosteron seviyeleri ve endometrial kalınlığı anlamlı olarak yüksek tespit edilirken; SHBG seviyeleri anlamlı olarak düşük bulundu. Endometrial kalınlığı 5mm'den büyük olan 17 hastadan 8 tanesinde endometrial patoloji tespit edildi.

Sonuç: Bu sonuçlarla; obezitenin, post-menopozal kadınlarda androjen hormonlan üzerinden endometrial karsinoma ve diğer patolojiler için bir risk faktörü oluşturabiliceği akılda bulundurulmalıdır.

(J Turkish-German Gynecol Assoc 2010; 11: 149-51)

A nahtar kelimeler: Serum androjen, endometrial kalınlık, obezite, post-menopoz

Geliş Tarihi: 13 Kasım 2010

K abul Tarihi: 03 Ağustos 2010

SHBG is responsible for the transport of sex hormones in the plasma, especially testosterone, dehydrotestosterone and estradiol (higher affinity for testosterone and lower for estradiol). It has a negative relationship with free testosterone and is used as an indirect indicator of androgenity (7).

Transvaginal sonography (TVS) is a non-invasive and reliable method for evaluating the uterus and endometrium (8).

In this study we investigated whether serum androgen levels and endometrial thickness differed in obese and non-obese postmenopausal women.

\section{Material and Methods}

Eighty postmenopausal women who applied to the menopause clinic of İstanbul Education and Research Hospital, Department of Obstetrics and Gynecology, between July 2004, were prospectively included in the study. These women had experienced natural menopause, had an FSH 
level greater than $40 \mathrm{mlU} / \mathrm{ml}$, were non-smokers; and at least one year had passed since their last menstrual period. Seven women who had previously used hormone treatment or a medication that could affect body mass index, and three women who had genital or systemic pathology, were excluded from the study. PAP smears and physical examinations were performed after obtaining patient histories. Complete blood count, liver and renal functional tests, hormone profile (FSH, $\mathrm{LH}$, E2, progesterone, prolactin, testosterone, free testosterone, androstenedione, DHEAS, SHBG, and fasting insulin levels) were carried out for each woman.

After excluding any systemic disease, age, height and weight of each woman were noted at the first visit. Blood samples were taken after 12 hours fasting for the evaluation of sex steroids. Samples were centrifuged at $3000 \mathrm{rpm}$ and serums were stored under $-20^{\circ} \mathrm{C}$ until evaluation of SHBG. A chemiluminescent enzyme immunometric assay technique was used for the determination of hormone concentrations, except SHBG, for which an enzyme linked immunosorbant assay (ELISA) was used.

Transvaginal ultrasonography was performed with a Toshiba 2700 SA ultrasonography machine, and the criteria given by the American College of Obstetricians and Gynecology in 1995 was used for the measurement of endometrial thickness. The evaluation was performed in the three planes (anterior-posterior, long axis, semi-axial). Fluid collection in the cavity was not added to the thickness when making the measurement. We performed fractional curettage when we detected an endometrial thickness value of $5 \mathrm{~mm}$ or more.

The women were allocated into two groups according to Body Mass Index (BMI), which was calculated as weight ( $\mathrm{kg}$ ) / height ${ }^{2}$ $\left(\mathrm{m}^{2}\right)$, and a cut-off value for obesity of $30 \mathrm{~kg} / \mathrm{m}^{2}$ used. Those with $\mathrm{BMI}>30 \mathrm{~kg} / \mathrm{m}^{2}$ were considered as the study group.

Statistical Package for Social Sciences (SPSS v. 11.0) was used for statistical analysis. Two independent sampled Student's t-test were used for the comparison of data between the two groups. Results were recorded as mean \pm SD. $p<0.05$ was considered significant. This study was approved by the local Ethics Committee.

\section{Results}

The mean ages and post-menopause intervals of the women in the study group were $52.54 \pm 6.87$ years and $5.43 \pm 5.62$ years respectively. The mean height was $156.17 \pm 6.26 \mathrm{~cm}$, weight $89.02 \pm 19.73 \mathrm{~kg}, \mathrm{BMI} 32.85 \pm 6.79 \mathrm{~kg} / \mathrm{m}^{2}$, and endometrial thickness $5.56 \pm 4.06 \mathrm{~mm}$.
The demographic characteristics of the women according to BMI are listed in Table 1. The hormonal concentrations and endometrial thicknesses of the two groups are compared in Table 2.

SHBG levels were significantly lower in the group in which BMI was greater than $30 \mathrm{~kg} / \mathrm{m}^{2}$, whereas free testosterone and endometrial thicknesses were significantly higher (Table 2).

Only one of the 17 women whose endometrial thickness was higher than $5 \mathrm{~mm}$ had a BMI less than $30 \mathrm{~kg} / \mathrm{m}^{2}$. Fractional curettage was performed in these 17 women, and endometrial carcinoma was found in two, complex atypical hyperplasia in one, simple endometrial hyperplasia in one, and endometrial polyp in four. No pathology was detected in nine of these women.

\section{Discussion}

The relation between obesity and the increased endometrial cancer risk is well established in a review by Kaaks et al. and explained by the increasing amount of bioavailable estrogens in the circulation and the endometrial tissue (9). After the menopause, the major source of estrogen is via peripheral aromatization of androgens, especially in the adipose tissue (9). Furthermore, hyperinsulinemia in obese women inhibits the synthesis of SHBG (9). As a result, obesity is associated with increasing levels of estrodial unbound to SHBG, which can freely diffuse to target tissues.

Many articles have reported a decrease in SHBG as the BMI increases (10-12), and we also found lower SHBG concentrations in the group which had the higher BMI.

Douchi et al. reported a prospective study in which a significant relationship was demonstrated between endometrial thickness and obesity (13). Warming et al. demonstrated a positive correlation between BMI and endometrial thickness in a study that included healthy post-menopausal women (14). Serin et al. reported that increased endometrial thickness was associated with obesity but not with hypertension (15). We also observed increased endometrial thickness among women with high $\mathrm{BMI}$ and furthermore, independently of these surveys, we evaluated the role of androgens for this relation and detected high levels of free testosterone in obese women with increased endometrial thickness.

Decreased SHBG concentrations as a result of increased BMI in post-menopausal women increase the free androgen and estrogen levels in the circulation, with a resultant increased risk of endometrial carcinoma. An increased endometrial thickness with increased BMI could be an indicator of this probable risk. The question then arises whether this increased

Table 1. Demographic characteristics of the two groups according to BMI

\begin{tabular}{|c|c|c|c|c|c|}
\hline & \multicolumn{2}{|c|}{$\begin{array}{l}\text { BMI < } 30 \\
(n=32)\end{array}$} & \multicolumn{2}{|c|}{$\begin{array}{r}\text { BMI } \geq 30 \\
(n=48)\end{array}$} & \multirow[b]{2}{*}{$\mathbf{p}$} \\
\hline & Mean & $\pm S D$ & Mean & \pm SD & \\
\hline Age (years) & 53.06 & 6.58 & 52.54 & 6.87 & 0.813 \\
\hline Parity $(n)$ & 3.31 & 1.66 & 3.08 & 1.50 & 0.653 \\
\hline Years post-menopause & 6.56 & 8.35 & 5.43 & 5.62 & 0.613 \\
\hline Height $(\mathrm{cm})$ & 155.25 & 5.30 & 156.17 & 6.26 & 0.633 \\
\hline Weight (kg) & 66.56 & 7.22 & 89.02 & 19.73 & 0.0001 \\
\hline
\end{tabular}


Table 2. Comparison of hormone concentrations and endometrial thickness according to BMI

\begin{tabular}{|c|c|c|c|c|c|}
\hline & \multicolumn{2}{|c|}{$\begin{array}{c}B M I<30 \\
(n=32)\end{array}$} & \multicolumn{2}{|c|}{$\begin{array}{r}\text { BMI } \geq 30 \\
(n=48)\end{array}$} & \multirow[b]{2}{*}{$\mathbf{p}$} \\
\hline & Mean & \pm SD & Mean & \pm SD & \\
\hline $\mathrm{FSH}(\mathrm{mlU} / \mathrm{ml})$ & 64.13 & 19.54 & 65.05 & 22.65 & 0.895 \\
\hline $\mathrm{LH}(\mathrm{mlU} / \mathrm{ml})$ & 28.59 & 16.30 & 23.31 & 15.26 & 0.321 \\
\hline Prolactin (ng/ml) & 6.14 & 4.34 & 8.51 & 3.75 & 0.085 \\
\hline Estradiol (pg/ml) & 26.15 & 9.64 & 21.78 & 4.06 & 0.061 \\
\hline Progesterone (ng/ml) & 0.28 & 0.08 & 0.27 & 0.09 & 0.675 \\
\hline Testosterone (ng/ml) & 0.24 & 0.15 & 0.20 & 0.16 & 0.458 \\
\hline Androstenedione (ng/ml) & 13.66 & 10.42 & 13.28 & 6.63 & 0.889 \\
\hline Insulin ( $\mu \mathrm{IU} / \mathrm{ml})$ & 12.39 & 9.97 & 15.01 & 12.20 & 0.480 \\
\hline Free testosterone (pg/ml) & 1.21 & 0.70 & 1.81 & 0.71 & 0.013 \\
\hline SHBG (nmol/l) & 95.01 & 64.77 & 53.96 & 33.07 & 0.012 \\
\hline Endometrial thickness (mm) & 3.77 & 3.96 & 5.56 & 4.06 & 0.008 \\
\hline
\end{tabular}

endometrial carcinoma risk is solely due to the increased estrogen concentration or not.

Allen et al. have evaluated the endogenous sex hormones and endometrial cancer risk in women in a prospective case control study (16). They concluded that high levels of free testosterone and estrogens are associated with an increased endometrial cancer risk in postmenopausal women (16). Furthermore, they suggested that the association of endometrial cancer risk with free testosterone levels is a result of peripheral conversion of androgens into estradiol. Also, SHBG was significantly inversely and BMI positively associated with risk.

In another prospective case control study by Lukanova et al,. it was concluded that increased endometrial cancer risk in postmenopausal women with high blood concentrations of androgens seems to be primarily due to their role as precursor hormones for estrogen synthesis (17).

Interestingly, we have detected endometrial adenocarcinoma in two subjects, complex atypical hyperplasia in one, and simple endometrial hyperplasia in three. Free testosterone levels of these cases were high and SHBG levels were low. Although our study did not definitively demonstrate a relationship between elevation of androgens and endometrial pathologies, it indicates that the probability of such a relationship should be kept in mind. Considering free testosterone and SHBG concentrations together with the endometrial thickness may help to detect endometrial pathologies.

Future studies are needed to demonstrate conclusively that elevated androgen levels, as well as increased estrogen, can give rise to endometrial pathologies in postmenopausal women.

\section{Conflicts of interest}

No conflict of interest is declared by authors.

\section{R eferences}

1. Burger HG. The endocrinology of the menopause. Maturitas 1996; 23: 129-36.

2. Rannevik G, Jeppsson S, Johnell O, Bjerre B, Laurell-Borulf $Y$, Svanberg L. A longitudinal study of the perimenopausal transition; altered profiles of steroid and pituitary hormones, SHBG and bone mineral density. Maturitas 1995; 21: 103-13.
3. Bancroft J, Cawood EH. Androgens and the menopause; a study of 40-60 year old women. Clin Endocrinol (Oxf) 1996; 45: 577-87.

4. Rozenberg S, Bosson D, Peretz A, Caufriez A, Robyn C. Serum levels of gonadotrophins and steroid hormones in the post-menopause and later life. Maturitas 1988; 10: 215-24.

5. Longcope C, Franz C, Morello C, Baker R, J ohnston J r CC. Steroid, and gonadotropin levels in women during the peri-menopausal years. Maturitas 1986; 8: 189-96.

6. Longcope $\mathrm{C}$. Adrenal and gonadal androgen secretion in normal females. Clin Endocrinol Metab 1986; 15: 213-28.

7. Berman DM, Rodrigues LM, Nicklas BJ, Ryan AS, Dennis KE, Goldberg AP. Racial disparities in metabolism, central obesity, and Sex Hormone Binding Globulin in postmenopausal women. J Clin Endocrinol Metab 2001; 86: 97-103.

8. Omodei U, Ferrazzi E, Ramazzotto F, Becorpi A, Grimaldi E, Scarselli G, et al. Endometrial evaluation with transvaginal ultrasound during hormone therapy: a prospective multicenter study. Fertil Steril 2004; 81: 1632-7.

9. Kaaks R, Lukanova A, Kurzer MS. Obesity, Endogenous Hormones, and Endometrial Cancer Risk: A Synthetic Review. Cancer Epidemiol Biomarkers Prev. 2002; 11: 1531-43.

10. Burger HG, DudleyEC, Cui J, Dennerstein L, HopperJ L. A prospective longitudinal study of serum testosterone, dehydroepiandrosterone sulfate, and sex hormone-binding globulin levels through the menopause transition. J Clin Endocrinol Metab 2000; 85: 2832-8.

11. Wei S, Schmidt MD, Dwyer T, Norman RJ, Venn AJ. Obesity and menstrual irregularity: associations with SHBG, testosterone and insulin. Obesity (Silver Spring) 2009; 17: 1070-6.

12. Akın F, Baştemir M, Alkiş E, Kaptanoğlu B. Associations between sex hormone binding globulin and metabolic syndrome parameters in premenopausal obese women. Indian J Med Sci 2008; 62: 407-15.

13. Douchi $T$, Yoshinaga $M$, Katanozaka $M$, Mitani $M$, Nagata $Y$ Relationship between body mass index and transvaginal ultrasonographic endometrial thickness in postmenopausal women. Acta Obstet Gynecol Scand 1998; 77: 905-8.

14. Warming L, Ravn P, Christiansen C. Visceral fat is more important than peripheral fat for endometrial thickness and bone mass in healthy postmenopausal women. Am J Obstet Gynecol 2003; 188: 349-53.

15. Serin SI, Ozcelik B, Basbug M, Ozsahin O, Yilmazsoy A, Erez R. Effects of hypertension and obesity on endometrial thickness. Eur J Obstet Gynecol Reprod Biol 2003; 109: 72-5.

16. Allen NE, Key TJ, Dossus L, Rinaldi S, Cust A, Lukanova A et al. Endogenous sex hormones and endometrial cancer risk in women in the European Prospective Investigation into Cancer and Nutrition (EPIC). Endocr Relat Cancer. 2008; 15: 485-97.

17. Lukanova A, Lundin E, Micheli A, Arslan A, Ferrari P, Rinaldi S et al Circulating levels of sex steroid hormones and risk of endometrial cancer in postmenopausal women. Int J Cancer. 2004; 108: 425-32. 